\title{
Effect of the Practices of Charcoal Producers on the Sustainability of Shea Tree in the North-central Nigeria
}

\author{
Garba I.D. ${ }^{1}$ and Muhammad-Lawal A. ${ }^{2}$ \\ ${ }^{1}$ Agricultural Economics Division, Nigerian Institute for Oil-palm Research (NIFOR) \\ P.M.B 1030, Benin City, Edo State, Nigeria \\ ${ }^{2}$ Department of Agricultural Economics and Farm Management, University of Ilorin, \\ P.M.B. 1515, Ilorin, Nigeria \\ Iibrahimdanfat@yahoo.com, ${ }^{2}$ Lawaz71@yahoo.com
}

\begin{abstract}
Shea tree produce the best quality charcoal, the tree is exploited in its natural habitat and listed as threatened species on the International Union for Conservation of Nature red list. The trading of charcoal has become a very lucrative venture in the North-central, Nigeria. The marketing activities, the practices of the charcoal producers toward the sustainability of shea tree and the level of sustainability of shea tree among charcoal producers prompted this study. A three-stage sampling technique was used to select 100 respondents drawn from five Local Government Areas across two states of North-central Nigeria. The total of 79 responses were found useful for the study. Descriptive statistics, budgeting techniques and multinomial logistic regression were used for data analysis. From the major findings, an average of $78.81 \mathrm{~kg}$ of charcoal was produced using $180.26 \mathrm{~kg}$ of inputs, while an average of net return of N1,470.75 was realized per processing cycle. Conversely, 309.38kg of charcoal was produced from an average shea tree of $2,457 \mathrm{~kg}$ and the net profit realized was $\$ 5,773.03$ per tree per season. Besides, a mean score of 2.4, indicating low index, suggests that majority of the charcoal producers have attitudes that were unfavorable for the sustainability of shea tree. While age, household size, extension contacts, fuelwood quantity, gender, labour, household size, educational level and charcoal quantity were the significant factors affecting the level of sustainability of shea tree $(p<0.05)$. Charcoal production is profitable but the practices and attitudes of the charcoal producers were not sustainable, thereby portending great risk for shea tree sustainability. There should be campaign on the regulatory harvest of shea tree. And Actors should be encouraged to inculcate the right practices towards the sustainability of shea tree.
\end{abstract}

Keywords: Shea tree, North-central, Multinomial logistic regression, Profitable, sustainability

\section{Introduction}

Shea tree (Vitellaria paradoxa) is over exploited in its natural habitat for charcoal production and listed as threatened specie on the International Union for Conservation of Nature (IUCN) red list. Shea tree is said to produce the best quality charcoal, that is stronger, bigger and last longer. Charcoal is virtually available all over Nigeria as many local communities have

Article history:

Received (January 27, 2020), Review Result (March 2, 2020), Accepted (April 11, 2020) 
perfected the technology of charcoal production, [1]. Charcoal producers sacrifice long term considerations of shea resources for a relative short term income. Shea tree is especially said to be overwhelmed by indiscriminate felling for charcoal which destroy the wild growing shea tree and its environment. Shea log harvesting for charcoal production and their marketing requires only minimal financial and human resources. In Nigeria, charcoal is used for cooking, roasting of (suya- barbecue, maize, plantain, cocoyam and yam), blacksmithing and bronze casting. The rate of substitution of charcoal for the alternative fuels had recently increased [2]. Charcoal constitutes the primary urban fuel in most part of Nigeria and is a major source of income. The trading business of charcoal in Nigeria has now become a very lucrative venture for anyone involved in it, whether as a retailer, wholesaler or supplier, [3]. Charcoal production represents a critical energy and economic cycle [4]. A large charcoal market also exists in Europe and Asia with prices ranging from $\$ 170$ to $\$ 300$ per MT.

The effect of charcoal production on human health cuts across the production cycle, ranging from wood logging, transportation, and wood residue carbonization in the kiln, to cooling, sieving, packaging and storage of bio char. The most deleterious impact emanates from the carbonization stage which is the stage where most gaseous emission takes place. Long term exposure of humans to gaseous emission during burning leads to respiratory problem. Charcoal is major source of income generation and environmental degradation in rural area [5].

The buying of charcoal involves numerous end-users who make frequent purchases, without much concern for the economic and environmental impacts of their consumption. Charcoal from shea trees therefore, threatens the long term sustainability of shea parkland and the livelihoods of the rural poor who depend on shea resources [6]. A significant proportion of shea trees used for charcoal production are unsustainably harvested. The bulk of charcoal wood is clear cut. This practice ultimately destroys the vegetation. Charcoal production may have adverse effects on the environment, its consequences include health implications, environmental degradation, decline in environmental productivity, loss of biodiversity, increase in evaporation and transpiration, disruption of hydrological cycle, accumulation of greenhouse gases which heighten unsustainable environment [7]. Increase in charcoal production increases pressure on the natural forest, unless establishment of plantations of most desired species of wood is taken into consideration. Continuous production of charcoal from shea tree will negatively affect its sustainability, which will lead to environmental hazard, loss of resources and also the potential of charcoal production as an instrument of economic development may not be fully realized [2]. The sustainability of shea tree here, lays emphasis on development not leading to irretrievable loss of the shea resources. Shea trees have value in themselves and not just as input in the economic process [8]. The activities of the charcoal producers must not exhaust the shea resources on which it depends. The concept of sustainability thus raises a starkly basic question: can the practices of the charcoal producers successfully maintain itself and its goals without exhausting the resources on which it depends?

Shea tree is poorly represented in protected areas and efforts to maintain their abundance are not yet put in place. The effect of the practices of charcoal producers is hazardous. These may cause extensive land degradation, decreasing shea tree density, vegetation cover and much other environmental degradation. Shea tree is important economically. However, its potentials for charcoal production are not widely documented in North-central Nigeria. The levels of sustainable practices of the charcoal producers and how they affect the sustainability of shea tree need to be investigated. This information will speed up any conservation efforts of the wild growing shea tree species. 
The broad objective of this study is to asses the effect of the charcoal producer's practices on the sustainability of shea tree in the North-central Nigeria. The specific objectives to be investigated are to:

1. estimate the cost and returns to charcoal production;

2. determine the practices and attitudes of the charcoal producers toward the sustainability of shea tree and

3. examine the determinants of the level of sustainability of shea tree among charcoal producers.

\section{Methodology}

\subsection{Study area}

The target population for this study are charcoal producers in North-central, Nigeria. The region is situated geographically in the middle belt of the country and is rich in natural land features. North-central is vital for the study due to the abundant concentration of shea trees [9]. Kwara and Niger State have the largest density of shea tree for charcoal activities in Northcentral [10] and [11]. Therefore, the two states formed the study area in North-central Nigeria.

Kwara State lies within latitudes $7^{\circ} 45^{\prime} \mathrm{N}-9^{\circ} 30^{\prime} \mathrm{N}$ and longitudes $2^{\circ} 30^{\prime} \mathrm{E}-6^{\circ} 23^{\prime} \mathrm{E}$. It covers a total land area of 36,825 square kilometers or $8 \%$ of the total area of Nigeria [12]. Kwara State consists of sixteen (16) Local Government Areas. The state shares an international boundary with the Republic of Benin [13]. The state is divided into four agricultural zones (Zone A, B, C, and D) by the Kwara State Agricultural Development Project [14]. It is located in the transitional zone between the deciduous woodland of the South and dry savannah of North of Nigeria [15]. Kwara State lies within a region described as tropical climate and are characterized by double rainfall maxima and has tropical wet and dry climate, each lasting for about six months [16] and [17]. The annual rainfall range from $1000 \mathrm{~mm}$ to $1500 \mathrm{~mm}$ [17] and the temperatures typically range from $33^{\circ}$ to $34^{\circ} \mathrm{C}$, while from February to April; the temperature is between $34.6^{\circ} \mathrm{C}$ and $37^{\circ} \mathrm{C}$.

Niger State is divided into three agricultural zones (Zones A, B, C or I, II and III) by the Niger State Agricultural Development Project (ADP), consisting of twenty five (25) Local Government Areas. Niger State is located between latitudes $8^{\circ} 11^{\prime} \mathrm{N}$ and $11^{\circ} 20^{\prime} \mathrm{N}$ and longitude $4^{0} 30^{\prime} \mathrm{E}$ and $7^{0} 20^{\prime} \mathrm{E}$. It shares a foreign border with the Republic of Benin in the North-West. The state covers an estimated land mass of 86,000 square kilometers, taking about $10 \%$ of Nigeria's total land mass, of which $85 \%$ is arable land. Niger State experiences distinct dry and wet seasons. The annual rainfall varies from $1,100 \mathrm{~mm}$ in the northern part of the state to $1,600 \mathrm{~mm}$ in the southern parts. The temperature ranges from $23^{\circ} \mathrm{C}$ to $37^{\circ} \mathrm{C}$ [18].

\subsection{Sampling procedure}

Three-stage sampling technique was used in the selection of respondents. The first stage involved the purposive selection of two (2) states in North-central Nigeria, specifically Kwara and Niger based on the highest density of shea tree. The second stage involved the purposive selection of five (5) Local Government Areas (LGAs) across the forty-one (41) LGAs in the two states of North-central Nigeria, based on the highest concentration of charcoal activities. The third stage involved the selection of twenty (20) respondents in each of the LGA through snowballing. The study sampled the total of one hundred (100) respondents that were randomly selected from two (2) Local Government Areas in Kwara State and three (3) Local Government 
Areas in Niger State. The total of seventy nine (79) responses were found useful for data analysis.

\subsection{Method of data collection/analytical techniques}

The study was based on primary data that were elicited with the aid of well structured questionnaire, which were administered to the charcoal producers. Both descriptive and inferential statistics was employed to analyze the data from the field survey. Descriptive tools used were: means, cross-tabulations, frequencies, ratios, percentages and likert scores. Other specific tools employed were: budgeting techniques and multinomial logistic.

\subsubsection{Returns to charcoal production activities}

Net profit $(\Pi)$ was used to assess the cost and returns to charcoal production activities for a specified period. Net profit is the Total Revenue minus Total Expenses, also called net income or net earnings and this can be specified as:

$$
\Pi=\sum T R_{i}-\sum T C_{i}
$$

Where:

$$
\sum T C_{i}=\sum T V C_{i}+\sum T F C_{i}
$$

Where:

$\mathrm{TR}=$ total revenue

$\Pi=$ net profit

TVC $=$ total variable cost.

$\mathrm{TFC}=$ total fixed cost

$\mathrm{TC}=$ total cost of production.

For ease of computation, the straight line method was used in depreciating the capital items that was included in computing fixed cost where applicable. It is necessary to depreciate the initial value of fixed assets in order to guide against over valuation of the cost incurred in each charcoal production cycle. The formula is given by:

$$
d=\left\{\frac{c-s}{n}\right\}
$$

Where:

$d=$ depreciation $(\#)$

$c=$ purchase value of the asset (cost) ( $\#)$

$S=$ salvage value, which is the value of the asset after its expected year of usage (\#)

$n=$ life span of the asset (years).

The operational efficiency was determined using return on investment (ROI) and Operating ratio $(\mathrm{OR})$ using the following formula:

$$
R O I=\frac{\text { Gain from investment }- \text { Cost }}{\text { Cost }} \times 100 \text { or } \frac{\Pi}{T C}
$$

The higher the coefficient of the ROI the more profit the enterprise. And operating ratio is given as

$$
\text { Operating ratio }=\frac{\text { operating exp enses }}{\text { Operating revenues }}
$$


The smaller the ratio the greater the enterprise's ability to generate profit if revenues decreases, is used as a measure of operational efficiency of any enterprise. It measures the business efficient use of capital resources and managerial resources.

\subsubsection{Multinomial logistic model}

Multinomial logit was employed to examine the determinants of the level of sustainability of shea tree among charcoal producers.

$$
\begin{gathered}
\operatorname{Pr}\left[Y_{i}=j\right]=\frac{\exp \left(X_{i}{ }^{\prime} \beta_{j}\right)}{\sum_{j=0}^{j} \exp \left(X_{i}^{\prime} \beta_{j}\right)} \\
=\frac{\eta_{j}}{\eta_{0}+\eta_{1}+\eta_{2}+\eta_{3}} j=0,1,2,3,
\end{gathered}
$$

Where: $\operatorname{Pr}\left[Y_{i}=j\right]=$ is the probability that any household's attitude on the sustainability of shea tree is ranked as not sustainable, moderately sustainable, poorly sustainable and sustainable as the last category and the baseline or reference of shea sustainability category,

$j=\quad$ is the level of sustainability of shea tree in the choice set, or the practices and attitudes toward the sustainability of shea tree

$X_{i}=$ is a vector of the predictor (exogenous) social and other production factors (variables)

$\beta_{j}=$ is a vector of the estimated parameters.

Equation (7) can be estimated by the method of maximum likelihood. In this model:

$$
P_{i}(Y=1)=\frac{1}{1+\sum_{J=1}^{J} \exp \left(X_{i} \beta_{j}\right)}
$$

Probability is obtained as follows:

$$
P_{i}(Y=j)=\frac{\exp \left(X_{i} \beta_{j}\right)}{1+\sum_{J=1}^{J} \exp \left(X_{i} \beta_{j}\right)}
$$

Where $j=1,2, \ldots . . J$ and $i=1,2, \ldots \ldots \ldots, N$ And therefore,

$$
P_{i}(Y=J)=\frac{\exp \left(X_{i} \beta_{j}\right)}{1+\sum_{J=1}^{J} \exp \left(X_{i} \beta_{j}\right)}
$$

However, the likert score of the practices and attitudes of the charcoal producers toward the sustainability of shea tree was averaged and a Composite Sustainability Index (CSI) ranging from 0 to 1 was determined for each producer and scored for each category as follows:. CSI < 0.25 was categorized as unsustainable ( 0 ); from 0.25 - 0.5 as poorly sustainable (1); from 0.5 0.75 as moderately sustainable (2); and $>0.75$ as sustainable (3) [19]. Where $Y=j_{i}$, where $j=$ sustainability level of shea tree; and $i=$ category of actors (charcoal producers).

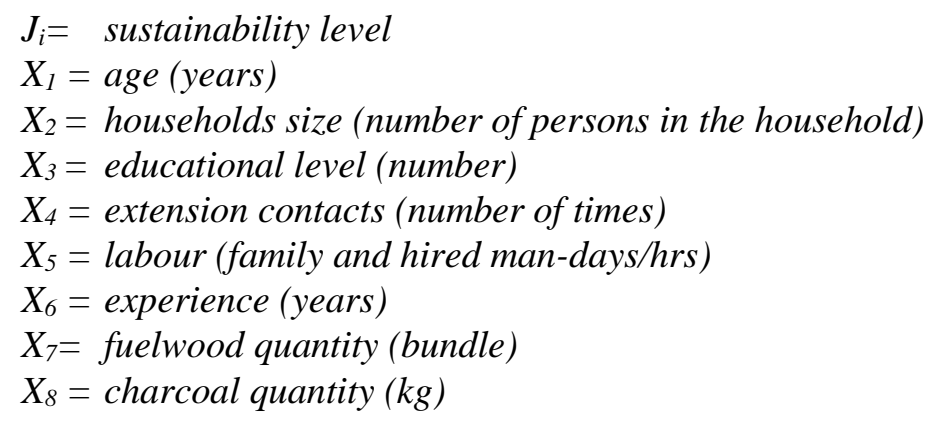


$d_{1}=$ marital status $($ married $=1$, otherwise $=0)$

$d_{2}=$ sex (dummy: 1 for male and 0 for otherwise)

$d_{3}=$ awareness of shea tree conservation (aware 1, otherwise 0)

$d_{6}=$ occupation (charcoal maker 1, 0 for otherwise)

\section{Results and discussion}

\subsection{Socioeconomic characteristics of the charcoal producers}

[Table 1] presents the socioeconomic characteristics of charcoal producers identified in the study area.

Table 1. Socioeconomic characteristics of charcoal producers

\begin{tabular}{|c|c|c|}
\hline Variables & Categories & $(\%)$ \\
\hline \multirow{5}{*}{ Age } & $20-30$ & 8.86 \\
\hline & $31-40$ & 26.58 \\
\hline & $41-50$ & 40.51 \\
\hline & $51-60$ & 18.99 \\
\hline & $>60$ & 5.06 \\
\hline \multirow{4}{*}{ Experience } & $1-10$ & 83.54 \\
\hline & $11-20$ & 15.19 \\
\hline & $21-30$ & 1.27 \\
\hline & $>30$ & 00.00 \\
\hline \multirow{5}{*}{ Education } & None & 00.00 \\
\hline & Non-formal & 59.49 \\
\hline & Primary & 25.32 \\
\hline & Secondary & 11.39 \\
\hline & Tertiary & 3.80 \\
\hline \multirow{6}{*}{ Household size } & $1-5$ & 6.33 \\
\hline & $6-10$ & 32.91 \\
\hline & $11-15$ & 36.71 \\
\hline & $16-20$ & 20.25 \\
\hline & $21-25$ & 2.53 \\
\hline & $>30$ & 1.27 \\
\hline \multirow{2}{*}{ Gender } & Male & 55.7 \\
\hline & Female & 44.3 \\
\hline \multirow{2}{*}{ Marital status } & Married & 81.08 \\
\hline & Otherwise & 18.99 \\
\hline \multirow{6}{*}{ Other occupation } & None & 00.00 \\
\hline & Civil servant & 5.06 \\
\hline & Trading & 44.3 \\
\hline & Artisan & 13.92 \\
\hline & Money lending & 00.00 \\
\hline & Farming & 36.71 \\
\hline \multicolumn{2}{|c|}{ Credit access } & 25.32 \\
\hline \multicolumn{2}{|c|}{ Membership of Association } & 15.19 \\
\hline \multicolumn{2}{|c|}{ Extension service } & 32.91 \\
\hline
\end{tabular}

[Table 1] shows that the modal age of charcoal producers fall within the age range of 31-40 and $41-50$ constituting $26.58 \%$ and $40.51 \%$ of the respondents respectively, while the mean age was reported to be 45 years. This is regarded as an active age range; this is because the modal age bracket and the mean age of the charcoal producers are noted for their energy, enthusiasm and creativity which have been recognized as being part of any nation's greatest assets. Further 
analysis depicts that the modal years of experience constituting $83.54 \%$ of the respondents falls within the range of 1-10 years and the mean years of experience was found to be 8 . Years of experience could determine the charcoal producer's ability to effectively harness the shea resources to their advantages, making them more productive in the industry and more detrimental to shea tree and its environment.

The analysis portrays that majority (59.49\%) of charcoal producers had no formal education, while $11.39 \%$ and $25.32 \%$ attained both secondary and primary education, and only $3.80 \%$ had tertiary education. The fact that respondents with tertiary education were not involved in charcoal production support the a priori belief that educated ones tend to migrate to the cities in search of white collar jobs while others remain in the village and live on the forest resources. The majority of the respondents $(36.71 \%)$ have $11-15$ household size. The mean household size was 12 people, with minimum household size of 4 persons and maximum of 36. Large household size is advantageous as labour intensive activities are mainly carried out by the household, although mutual labour sharing is also common. The analysis depicts majority (55.7\%) of charcoal producers to be men. This is in line with the findings of [2] and [20] which reported more than 50\% of men's involvement in charcoal production in Miombo woodland in Tanzania and in Iseyin LGA of Oyo State, Nigeria respectively. Majority (81.08\%) of the respondents were married. This is because marriage is considered to be integral part of religion which is held in high esteem in the study area.

The analysis of the result shows that majority of charcoal producers have other source of income from trading and farming constituting $(44.3 \%)$ and $(36.71 \%)$ respectively. Income from other sources could help in boosting the productive capital of the charcoal producers. Majority of the charcoal producers $(74.68 \%$ ) had no access to credit. This could be attributed to the fact that many regard charcoal productions as an illegal activity because of the law that prohibits the cutting of trees of economic values as shea. The result revealed that only $15.19 \%$ of charcoal producers belong to an association. This could be due to the fact that they are not structured in their production activities. Majority (67.09\%) of charcoal producers had no access to extension services because majority engaged themselves in charcoal production activities unlawfully.

\subsection{Returns to charcoal production activities}

This section presents the net returns of the charcoal producers per processing cycle and per tree per season [Table 2] as well as the corresponding return on investment (ROI) and operating ratio (OR).

Table 2. Cost and returns to charcoal production per processing cycle and per tree

\begin{tabular}{|c|c|c|c|c|c|}
\hline \multicolumn{2}{|c|}{ Activities per processing cycle } \\
\hline \multicolumn{2}{|c|}{ Processing cycle (2 days) } & \multicolumn{3}{c|}{ Per season (1 year) } \\
\hline Variables & Quantity & Amount & Quantity & \multicolumn{2}{|c|}{ Amount } \\
\hline Output value (N) (A) & & $2,593.08$ & & $10,178.60$ & \\
\hline Output quantity (kg) & 78.81 & & 309.38 & & \\
\hline Labour (Manday) & 2.16 & 39.58 & $1.57^{*}$ & $155.41^{*}$ & \\
\hline Transport & & 62.74 & & 246.37 & \\
\hline Fuelwood/logs (kg) & $180.26^{*}$ & $956.27^{*}$ & $2,475^{*}$ & $3,754.10^{*}$ & \\
\hline Kerosene (Lt) & 0.01 & 2.83 & 0.08 & 11.12 & \\
\hline Comm. Agents & & 27.77 & & 109.05 & \\
\hline Total VC (B) & & $1,089.20$ & & $4,276.945$ & \\
\hline Rent & & 9.11 & & 35.79 & \\
\hline Fees & & 3.32 & & 13.02 & \\
\hline Depreciation charges & & 20.70 & & 81.28 & \\
\hline
\end{tabular}




\begin{tabular}{|c|c|c|}
\hline $\operatorname{TFC}(\mathrm{C})=$ & 33.13 & 130.09 \\
\hline $\mathrm{TC}(\mathrm{D})=(\mathrm{B}+\mathrm{C})$ & $1,122.33$ & $4,405.03$ \\
\hline Net profit $(E)=(A-D)$ & $1,470.75$ & $5,773.03$ \\
\hline Operating ratio $(\mathrm{D} / \mathrm{A})$ & 0.43 & 0.43 \\
\hline $\mathrm{ROI}(\{\mathrm{E} /\} \mathrm{D})$ & 1.31 & 1.31 \\
\hline
\end{tabular}

As shown in [Table 2], charcoal producer's wood logs cost of $\$ 956.27$ presents the largest and the most important, accounting for about $87.80 \%$ of the TVC. Lots of wood logs are heavily consumed during charcoal production. labour cost of $\$ 39.58$ and transport cost of $\$ 62.74$ presents the highest after wood logs cost. This is due to the fact that charcoal production demands high labour for cutting of trees, chopping in into logs, packing, burning, bagging, sand and leaf piling. Besides, wood logs has to be transported to charcoal producing unit if is not produced at the point of logging and charcoal has to be transported to the point of sale. Fixed cost constituted only $2.95 \%$ of the TC since charcoal production requires minimal capital items.

Equally, charcoal producers produced an average of $78.81 \mathrm{~kg}$ of charcoal at a unit price of $\$ 32.90$ and $\$ 1,414.7 / \mathrm{bag}$. The cost of producing a bag (43kg) of charcoal was estimated to be $\$ 612.40$ at $\$ 14.24$ per $\mathrm{kg}$. The result showed that the revenue realized from the sale of the charcoal exceeded the actual cost of production. The net profits was $\$ 1,470.75$ per processing cycle, which implies that the total cost incurred during production was less the selling price. This positive financial return is an indication that charcoal activity is profitable. Charcoal production shows a glaring return to investment and operating ratio of 1.31 and 0.43 respectively. This implies that $\$ 1.31$ was realized in every $\$ 1$ worth of investment and only $43 \%$ of the gross income is spent on running expenses, i.e. $43 \%$ of the sales revenue would be used to cover cost of charcoal sold and other operating expenses of charcoal. The higher the rate of return on investment, the more the profit; and the smaller the operating ratio, the greater the enterprise's ability to generate profit. They both measure the operational efficiency of any enterprise as well as the efficiency of the use of capital and managerial resources. Charcoal production presented a high ROI and a lower OR. This is due to the fact that fixed and variable costs incurred during production process were minimal, and equally little capital can start up charcoal production venture since less capital items are needed in the production process. However, there were social costs which affect the sustainability of shea tree due to the fact that their activities are destructive in nature. Indiscriminate harvesting of shea tree for charcoal can lead to increasing damage to shea tree habitat and deplete the shea tree density.

The analysis in [Table 2] also shows the estimate of cost and returns to charcoal production activities per tree per season and details include the breakdown of the cost components, quantity and the output value. In addition, an average shea tree of $2,457 \mathrm{~kg}$ was used for charcoal production, taking in to consideration a shea tree trunk diameter of $1 \mathrm{~m}$ which is equivalent to 39.37 inch and a shea tree trunk diameter of 12 -inch, equivalent to 0.75 ton. For the context of this analysis, $8 \mathrm{~kg}$ of wood produce $1 \mathrm{~kg}$ of charcoal. Therefore, $309.38 \mathrm{~kg}$ of charcoal was produced per tree from an average shea tree, which is equivalent to 7.19 bags of charcoal at $43 \mathrm{~kg}$ per bag. The cost of production was found to be $\$ 4,405.57$ and the revenue realized was $\$ 10,178.60$ at the cost of $\$ 14.24$ for producing $1 \mathrm{~kg}$ of charcoal and at the unit price of $\$ 32.90$ for $1 \mathrm{~kg}$. The net profit realized was $\$ 5,773.03$ per tree per season.

\subsection{Practices and attitudes of the charcoal production toward sustainability}

[Table 3] presents the practices and attitudes of charcoal producers on the sustainability of shea tree. 
Table 3. Attitudes of the charcoal producers on the sustainability of shea tree

\begin{tabular}{|c|c|c|c|c|c|c|}
\hline & & S/A & Ag & $\mathbf{N}$ & D & S/D \\
\hline & Attitudes & $\%$ & $\%$ & $\%$ & $\%$ & $\%$ \\
\hline & onsidering shea tree as a threatened specie & 6.33 & 6.33 & 8.86 & 54.43 & 24.05 \\
\hline & Preservation of shea for sustainable use & 3.8 & 10.13 & 20.25 & 36.71 & 29.11 \\
\hline & king efforts to keep shea tree on farm land & 11.39 & 7.59 & 30.38 & 26.58 & 24.05 \\
\hline The need & $\begin{array}{l}\text { o establish shea tree plantation to sustain the plant } \\
\text { specie }\end{array}$ & 8.86 & 5.06 & 35.44 & 32.91 & 17.72 \\
\hline Consider & ng destroying shea tree not a threat to its survival & 7.59 & 6.33 & 15.19 & 50.63 & 20.25 \\
\hline Consideri & $\begin{array}{l}\text { ig that the benefits derived from shea tree warrant } \\
\text { its cultivation }\end{array}$ & 3.80 & 5.06 & 2.53 & 25.32 & 63.29 \\
\hline Give & n equal protection to shea as other tree crops & 3.80 & 6.33 & 6.33 & 30.38 & 53.16 \\
\hline Conside & $\begin{array}{l}\text { ring that shea tree should be meant for shea fruit } \\
\text { collection alone }\end{array}$ & 18.99 & 20.25 & 20.25 & 24.05 & 16.46 \\
\hline & None collection of unripe shea fruit & 34.18 & 37.97 & 12.66 & 6.33 & 8.86 \\
\hline Cutti & ig of only dead shea tree for domestic energy & 11.39 & 13.92 & 10.13 & 32.91 & 30.38 \\
\hline Avoi & lance of bush burning around shea vegetation & 15.19 & 16.46 & 15.19 & 24.05 & 29.11 \\
\hline Non cuttir & $\begin{array}{l}\text { g of standing shea tree during farm cultivation and } \\
\text { other purposes }\end{array}$ & 34.18 & 55.70 & 2.53 & 5.06 & 2.53 \\
\hline Cutting & f shea tree is a threat to its mgt and sustainability & 3.80 & 6.33 & 3.80 & 49.37 & 36.71 \\
\hline Cor & sidering replanting of shea tree after cutting & 3.80 & 6.33 & 6.33 & 43.04 & 40.51 \\
\hline & ea is the worst tree for production activity & 8.86 & 5.06 & 8.86 & 36.71 & 40.51 \\
\hline Cutti & ng only dead shea tree for production activity & 8.86 & 5.06 & 8.86 & 58.23 & 18.99 \\
\hline Cutt & ing branch of life shea tree is not appropriate & 2.53 & 5.06 & 7.59 & 41.77 & 43.04 \\
\hline $\mathrm{Cu}$ & ting branch of dead shea tree is appropriate & 53.16 & 34.18 & 2.53 & 1.27 & 8.86 \\
\hline Non-cl & $\begin{array}{l}\text { tting of entire standing shea tree for production } \\
\text { activity }\end{array}$ & 39.24 & 43.04 & 5.04 & 1.27 & 11.39 \\
\hline Consi & $\begin{array}{l}\text { dering production activity a threat to shea tree } \\
\text { sustainability }\end{array}$ & 50.63 & 36.71 & 2.53 & 1.27 & 8.86 \\
\hline LEVEL O & SUSTAINABILITY & & & & & \\
\hline$<0.25$ & 10. & & & & & \\
\hline $0.25-0.50$ & 55 & & & & & \\
\hline $0.51-0.75$ & 26. & & & & & \\
\hline$>0.75$ & 7.5 & & & & & \\
\hline
\end{tabular}

Field Survey 2017

The analysis in [Table 3] shows that majority (78.48) of charcoal producers disagreed that shea tree is a threatened species of plant. This could be attributed to the fact that they are ignorant of the devastating effect of cutting down shea tree for charcoal. Furthermore, most of the practices and attitudes of the charcoal producers were found to be unsustainable for shea tree sustainability. Majority disagreed to favorable practices. Further analysis on the practices and attitudes of the charcoal producers toward shea tree sustainability revealed that they were not sustainable, having mean scores of 2.3. This implies that they disagree to positive practices and attitudes; it can however be deduced that their practices and attitudes on the sustainability of shea tree are not sustainable. The implication of this is that majority of them viewed shea tree as a wild growing plant provided by nature and a quick source of income, therefore giving shea tree protection or planting shea tree is not the priority. The acts of chopping down shea tree for charcoal need to be regulated for future exploration of its resources. Charcoal producers 
burn down shea logs during charcoal making without realizing its implication on the shea tree vegetation. Shea log is the most important input heavily consumed during charcoal production since it produces the best quality charcoal.

Equally, the analysis depicts the overall practices and attitudes of the charcoal producers; $55.7 \%$ and $26.58 \%$ to be poorly and moderately sustainable respectively, having $0.25-0.50$ and 0.51-0.75 composite sustainability index respectively. It can be deduced that majority of the charcoal producers $(65.73 \%)$ have practices and attitudes that are at best, poorly sustainable towards the sustainability of shea tree.

\subsection{Determinants of level of sustainability of shea tree among charcoal producers}

The result of the multinomial logistic regression on the determinants of the level of sustainability of shea tree with respect to the practices and attitudes of charcoal producers toward shea tree conservation is presented in [Table 4]. The level of the sustainability of shea tree is assumed to be influenced by the socioeconomic characteristics of the charcoal producers and other production factors.

Table 4. Multinomial logit on sustainability of shea tree

\begin{tabular}{|c|c|c|c|c|c|c|c|}
\hline Variables & Coef. & Std. Err. & $\mathrm{Z}$ & $\mathrm{P}>|\mathrm{z}|$ & RRR & & \\
\hline Constants & 2.751715 & 2.859584 & 0.96 & 0.336 & & $\operatorname{Prob}[\mathrm{Y}=0]$ & \\
\hline Age $\left(\mathrm{X}_{1}\right)$ & 0.169399 & 0.070461 & 2.4 & $0.016 * *$ & 0.844172 & & \\
\hline TotalHH $\left(\mathrm{X}_{2}\right)$ & 0.325725 & 0.149254 & 2.18 & $0.029 * *$ & 1.385035 & & \\
\hline Edulevel $\left(\mathrm{X}_{3}\right)$ & 0.410149 & 0.452504 & 0.91 & 0.365 & 1.507042 & & \\
\hline ExtenC. $\left(\mathrm{X}_{4}\right)$ & 2.571631 & 1.18203 & 2.18 & $0.030 * *$ & 13.08715 & & \\
\hline Labour $\left(\mathrm{X}_{5}\right)$ & $8.28 \mathrm{E}-05$ & 0.000638 & 0.13 & 0.897 & 0.999917 & & \\
\hline Exp. $\left(\mathrm{X}_{6}\right)$ & 0.099182 & 0.110477 & 0.9 & 0.369 & 1.104267 & & \\
\hline Flwdqnty $\left(\mathrm{X}_{9}\right)$ & 0.134363 & 0.062843 & 2.14 & $0.033 * *$ & 0.874273 & & \\
\hline Charcqnty $\left(\mathrm{X}_{11}\right)$ & 0.000344 & 0.000305 & 1.13 & 0.26 & 1.000344 & & \\
\hline Mart.st. $\left(\mathrm{d}_{1}\right)$ & 0.054233 & 0.870748 & 0.06 & 0.95 & 1.05573 & & \\
\hline Gender $\left(\mathrm{d}_{2}\right)$ & 2.35692 & 1.037582 & 2.27 & $0.023 * *$ & 10.55839 & & \\
\hline Awarn.Cn. $\left(\mathrm{d}_{3}\right)$ & 4883905 & 0.933629 & 0.52 & 0.601 & 1.629691 & & \\
\hline Occupation $\left(\mathrm{d}_{6}\right)$ & 0.017073 & 0.869266 & 0.02 & 0.984 & 1.01722 & & \\
\hline Constants & 4.462269 & 2.528386 & 1.76 & 0.078 & - & $\operatorname{Prob}[\mathrm{Y}=1]$ & \\
\hline Age $\left(\mathrm{X}_{1}\right)$ & 1159337 & 0.053132 & 2.18 & $0.029 * *$ & 0.890534 & & \\
\hline TotalHH $\left(\mathrm{X}_{2}\right)$ & 0.142385 & 0.129181 & 1.1 & 0.27 & 1.15302 & & \\
\hline Edulevel $\left(\mathrm{X}_{3}\right)$ & 0.213017 & 0.367597 & 0.58 & 0.562 & 0.808143 & & \\
\hline ExtenC. $\left(\mathrm{X}_{4}\right)$ & 3.008404 & 1.040381 & 2.89 & $0.004 * *$ & 20.25504 & & \\
\hline Labour $\left(\mathrm{X}_{5}\right)$ & 0.001225 & 0.000569 & 2.15 & $0.031 * *$ & 0.998776 & & \\
\hline Exp. $\left(\mathrm{X}_{6}\right)$ & 0.042226 & 0.088805 & 0.48 & 0.634 & 0.958653 & & \\
\hline Flwdqnty $\left(\mathrm{X}_{9}\right)$ & 0.053906 & 0.047196 & 1.14 & 0.253 & 0.947521 & & \\
\hline Charcqnty $\left(\mathrm{X}_{11}\right)$ & 0.000393 & 0.000264 & 1.49 & 0.137 & 1.000393 & & \\
\hline Mart.st. $\left(\mathrm{d}_{1}\right)$ & 0.954892 & 0.725931 & 1.32 & 0.188 & 0.384854 & & \\
\hline Gender $\left(\mathrm{d}_{2}\right)$ & 1.752914 & 0.846223 & 2.07 & $0.038 * *$ & 5.771395 & & \\
\hline Awarn.Cn. $\left(\mathrm{d}_{3}\right)$ & 0.934992 & 0.758427 & 1.23 & 0.218 & 2.547192 & & \\
\hline Occupation $\left(\mathrm{d}_{6}\right)$ & 0.312017 & 0.71111 & 0.44 & 0.661 & 1.366178 & & \\
\hline Constants & 2.831539 & 3.405307 & 0.83 & 0.406 & & $\operatorname{Prob}[\mathrm{Y}=2]$ & \\
\hline Age $\left(\mathrm{X}_{1}\right)$ & 0.054888 & 0.066911 & 0.82 & 0.412 & 0.946591 & & \\
\hline TotalHH $\left(\mathrm{X}_{2}\right)$ & 0.447666 & 0.207834 & 2.15 & $0.031 * *$ & 1.564655 & & \\
\hline Edulevel $\left(\mathrm{X}_{3}\right)$ & 1.686732 & 0.75188 & 2.24 & $0.025 * *$ & 0.185124 & & \\
\hline ExtenC. $\left(\mathrm{X}_{4}\right)$ & 5.089889 & 1.593989 & 3.19 & $0.001 * *$ & 162.3719 & & \\
\hline Labour $\left(\mathrm{X}_{5}\right)$ & $2.24 \mathrm{E}-05$ & 0.000657 & 0.03 & 0.973 & 1.000022 & & \\
\hline Exp. $\left(\mathrm{X}_{6}\right)$ & 0.310634 & 0.186784 & 1.66 & 0.096 & 0.732982 & & \\
\hline Flwdqnty $\left(\mathrm{X}_{9}\right)$ & 0.023561 & 0.066582 & 0.35 & 0.723 & 1.023841 & & \\
\hline Charcqnty $\left(\mathrm{X}_{11}\right)$ & 0.002958 & 0.001444 & 2.05 & $0.040 * *$ & 0.997047 & & \\
\hline
\end{tabular}




\begin{tabular}{|c|c|c|c|c|c|c|c|}
\hline Mart.st. $\left(\mathrm{d}_{1}\right)$ & 0.5644 & 1.061443 & 0.53 & 0.595 & 0.568702 & & \\
\hline Gender $\left(\mathrm{d}_{2}\right)$ & 1.583357 & 1.135884 & 1.39 & 0.163 & 4.871279 & & \\
\hline Awarn.Cn. $\left(\mathrm{d}_{3}\right)$ & 0.970442 & 1.169171 & 0.83 & 0.407 & 2.639112 & & \\
\hline Occupation $\left(\mathrm{d}_{6}\right)$ & 0.330218 & 1.022701 & 0.32 & 0.747 & 1.391271 & & \\
\hline \multicolumn{2}{|l|}{ Number of obs $=78$} & & & & & & \\
\hline LR chi $(36)=60.31$ & & & & & & \\
\hline
\end{tabular}

Field Survey 201

The Multinomial Logistic Regression (MLR) analyses in Table 4 reported a pseudo $\mathrm{R}^{2}$ of 0.2975 , which shows the strength and the fitness of the model and is regarded as highly satisfactory. Relative Risk Ratio (RRR) was generated to predict how any change in variable will increase the likelihood of the charcoal producer's practices and attitude to fall in one sustainability group or move to the other. The model had a chi-square of 60.31 and is significant with probability value of 0.0068 . The model is statistically significant, which suggest that the interaction effect is contributing significantly to the full model and should be retained. Because the presence of relationship between the response variable and combination of explanatory variable included in this model is based on the statistical significance of the final model's chisquare. This depicts the presence of high interaction effect between the response and explanatory variables. Sustainable practice was used as the base outcome or the reference of shea tree sustainability categories.

In the unsustainable category prb $(Y=0)$. The variables of age, household size, fuelwood quantity, extension contacts and gender were found to be positive and significant. It's an indication that they have significant effect on the level of sustainability of shea tree. From the analyses, age and fuelwood quantity RRRs were $<1$. This signify that the risk of the charcoal producer's practice and attitude to fall in the unsustainable group decreases relative to the risk of being sustainable as age and fuelwood quantity increases. This implies that even as any of the variable increases, the chance of the charcoal producer's practice or attitude to remain unsustainable decreases. In other words, the sustainable group outcome is more likely. In addition, the variable of household size, extension contacts and genders' RRR were found to be greater than $>1$. This suggests that any increase in the number of persons in the family, number of extension contacts and number of males, will increase the charcoal producer's practices or attitudes on the sustainability of shea tree to remain unsustainable. This indicates that the risk of their practices and attitudes toward the sustainability of shea tree to fall in the unsustainable group increases. In other words, the comparison group outcome is more likely.

In the poorly sustainable group, age, extension contact, gender and labour were found to have positive influence on the level of sustainability of shea tree. But age and labour's RRR were found to be $<1$ which implies that the risk of the outcome of their practices and attitudes to be poorly sustainable relative to the risk of the outcome falling in the reference group decreases with the increase in age and labour. While extension contact and gender had their RRR to be $>1$, this means that the practices and attitudes of charcoal producers to remain poorly sustainable increases with any unit increase in the number of extension contacts and number of males.

In the comparison group of the prob $\mathrm{Y}=2$, the variables of education, extension contact, total household and charcoal quantity were all significant. Extension contacts and total household's RRRs were $>1$. The implication of this is that, the risk of the charcoal producer's practices and attitudes toward shea tree sustainability to remain moderately sustainable compare to the risk of falling in the sustainable group increases, with any unit increase in extension visits and 
household size. While the RRRs of educational level and charcoal quantity were $<1$, which suggests that the likelihood of the practices and attitudes of the charcoal producer's to be moderately sustainable decrease with the increase in educational level and charcoal quantity. It's logical to deduce that the sustainability of shea tree can be ensured even when it is use for charcoal production, if is not the clear-cutting of standing shea tree to increase production; also educational level is expected to give charcoal producers sense of reasoning on the danger their practices might pose to the sustainability of shea resources. And in order not to jeopardize the source of income, charcoal producers will choose to regulate their activities; therefore the reference group is more likely. This study on determinants of level of sustainability follows similar trend with the studies of [21] and [22].

\section{Conclusion and recommendations}

\subsection{Conclusion}

The production of charcoal was dominated by mostly productive age men having several years of experience. The practices of the charcoal producers were profitable but unsustainable toward the sustainability of shea tree.

And the levels of sustainability were influenced by their socioeconomic characteristics and production resources.

\subsection{Recommendations}

The study proffered the following recommendations based on the research findings:

(1) Although commercialization of charcoal production from shea logs provides tangible monetary benefits to rural people in North-central Nigeria, it also threatens the long-term survival of the shea tree resources. There should be restriction to check over use of shea resource and government should promote shea tree planting to enhance its abundance.

(2) Similarly, charcoal prices do not reflect the used value due to the fact that shea trees are mostly harvested freely in the wild at little or no cost. Producers could be forced to obtain license or pay fees; also revenues from the activities can be reinvested in the establishment of plantation and woodlots for the purpose of helping the natural regeneration of shea tree.

(3) There should be conservation awareness of the vulnerable shea specie. Similarly, campaign on regulatory harvest of shea tree for charcoal can ensure its sustainability. The bylaws that prohibit the cutting of trees of economic value like shea should be strengthened and enforced.

(4) There should be enlightenment, on the effect of the charcoal producers' unfavorable practices on shea tree vegetation and the right practices on which the sustainability of shea tree depends.

\section{References}

[1] Awoyemi T. T., Amao, A. O., and Fatogun, O., "Household expenditure pattern on energy consumption in ibadan, oyo state Nigeria," Journal of Economics and Rural Development, vol.15, no.1, pp.79-87, (2006)

[2] Olagunju F. I., "Cost and returns to charcoal production in iseyin local government area of oyo state," Nigeria ASSET Series C, ASSET International Journal, vol.1, no.1, pp.21-37, (2006)

[3] William M. and Pinto F., "Energy supply demand integrations workshop on alternative energy strategies mit press," Cambridge, pp.230-257, (2008) 
[4] Jamala G. Y., Abraham P., Joel L., and Asongo A., "Socioeconomic implications of charcoal production and marketing in Nigeria," Journal of Agriculture and Veterinary Science (IOSR-JAVS), vol.5, no.4 (Sep. - Oct. 2013), pp.41-45, www.iosjournals.org, (2013)

[5] Kammen D.M and Lew D.J., "Review of technologies for the production and use of charcoal. renewable and appropriate laboratory report," National Renewable Energy Laboratory, Golden USA, (2005)

[6] Shively G., Jagger P., "Sserunkuuma D., Arinaitwe A., and Chibwana, C., Profits and margins, (2010)

[7] Ogwumike F.O. and U. M. Ozughalu, "Growth, poverty and environment in natural resource, the environment and sustainable development." Selected papers for the 2001 Annual Conference of the Nigeria's Economic Society, (2001)

[8] Soren S. O., "Sustainability concepts: the broad concepts of "weak" and "strong" Sustainability," Issues 2: pp.17-18, www.houseoffutures.dk, (2012)

[9] Olaoye J. O., Journal of Sustainable Agriculture and the Environment. Dilution/Clarification Protocol (JSAE), vol.3, no.2, pp.353-360, (2001)

[10] Odebiyi J.A, Bada S.O., Awodoyin R.O., Oni, P.L., and Omoloyo A.A., "West african journal of applied ecology," no.5, pp.31-39, (2004)

[11] Suleiman M.A.T., "A report on the assessment of potentials for shea nut in selected local government areas in niger state," (GTZ-EoPSD) Baseline Conducted in 2008, pp.46, (2008)

[12] Fakayode S.B, Babatunde R.O, and Ajao R., "Productivity of cassava based production systems in the guinea savannah: case study of Kawra state Nigeria,” America-Eurasian Journal of Scientific Research, vol.3, no.1, pp.33-39, (2008)

[13] Taiwo S., "Rapid assessment of the impact of liberalization and foreign private investment in agriculture for food security and food sovereignty in nigeria: a case study of kwara state report of a research conducted as part of the "right to food as human right" project," Trade and Sustainable Development Series no.2, Development Information Network and Heinrich Boll Foundation, (2005)

[14] Kwara Agricultural Development Project (1998-2004): Crop and Area Yield Survey, Annual Report, Kwara State Ministry of Agriculture and Rural Development KWMAR (2004): Planning, Monitoring and Evaluation Department (PME) Annual Report, (2004)

[15] Jimoh H.I., "Erosion tolerance range of land use surfaces: implication on land resource use and management techniques in Ilorin Nigeria," International Journal of Environmental Study, vol.60, pp.446-450, (2003)

[16] Olanrewaju R. M., "Climate and the growth cycle of yam plant in guinea savannah ecological zone of kwara state, Nigeria," Journal of Meteorological and Climate Science, vol.7, pp.43-48, (2009)

[17] Akpenpuun T.D., and Busari R.A., "Impact of climate on tuber crops yield in Kwara state, Nigeria," American International Journal of Contemporary Research, vol.3, no.10, pp.52-57, (2013)

[18] Sallawu H., Tanko L., Nmadu J.N., and Coker A.A., "Poverty status of farm households in selected local government areas in Niger State, Nigeria," Asian Journal of Agricultural Extension, Economics and Sociology along Uganda's charcoal value chain International Forestry Review vol.12, no.3, (2016)

[19] Kaushalya R., Gayatri M., Satish J., Praveen V., and Thaligavathi N., "Measuring the agricultural sustainability spatial evaluation of development in watershed proects Indian,” Journal of Soil Conservation, vol.44, no.2, (2016)

[20] Luoga E. J., Witkowski E.T.F., and Balkwill K., "Economics of charcoal production in miombo woodlands of eastern Tanzania: some hidden costs associated with commercialization of the resources," Journal of Ecological Economics, vol.35, no.2000, pp.243-257, (2000)

[21] Kadiri F., Eze C., Orebiyi S., and Nwaiwu I., "Determinants of sustainability of paddy rice production in niger delta region of Nigeria," Journal of Economics and Sustainable Development, vol.5, no.14, (2014)

[22] Qirui L., Amjath-Babu T.S., Peter Z., Zhen L., and Klaus M., "Sustainability of small-holder agriculture in semi-arid areas under land set-aside programs: a case study from china's loess plateau," Molecular Diversity Preservation International MDPI Journals. Sustainability, vol.8, (2016) DOI:10.3390/su8040395 www.mdpi.com/journal/sustainability 
This page is empty by intention. 